学術論文

\title{
磁束集中型振動発電装置を用いた歩行発電
}

\section{Generating Electricity during Walking with Concentrated Flux Type Vibration Generator}

\author{
佐藤 駿*1 (学生員), 北山 文矢 ${ }^{* 1}\left(\right.$ 正員), 岡田 養二 ${ }^{* 1}($ 正員 $)$, 近藤 良 ${ }^{* 1}$
}

Shun SATO (Stu. Mem.), Fumiya KITAYAMA (Mem.), Yohji OKADA(Mem.), Ryou KONDO

\begin{abstract}
This paper presents an electromagnetic vibration generator for harvesting walking energy, which is used a concentrated flux array. This array is arrangement of magnets which concentrates magnetic fluxes on one side of the array and prevents the magnetic saturation in the yoke. The generation electricity in walking is calculated with the acceleration which is measured on leg. By comparing the calculated electric power of the proposed and the conventional generator which uses N-S array, we clarified that the proposed generator produces $14 \%$ higher power than the conventional generator.
\end{abstract}

Keywords: energy harvesting, electromagnetic vibration generator, concentrated flux array, halbach array, vibration of moving body, induced voltage.

(2018 年 10 月 20 日受付, 2019 年 2 月 27 日再受付, 2019 年 4 月 5 日再々受付)

\section{1 緒言}

現在，電池を代替する持続的電源として環境発電 (エネルギーハーベスティング）に対する注目が高ま ってきている $[1]$ 。環境発電とは我々の身の回りにある 微小なエネルギー，例えば太陽光や風力，振動を電力 に変換する技術である。環境発電の応用として IoT(Internet of Things)機器用のセンサへの電源供給が 挙げられる[2]。従来の電池による電源供給では定期的 な電池交換が必要であること, さらに交換済み電池に よるごみの増加を招くということが課題として認識さ れている[3]。電源供給として環境発電を活用すること でこのような問題を解決できると考えられる。

IoT の応用としては構造体のセンシングやインフラ 設備のモニタリング[4]などが挙げられるが, 筆者は移 動体のモニタリングの一つである小児や老人の見守り システムに注目した。これは，センサによって得られ た見守り対象者の位置情報を保護者に伝えるシステム である。これにより迷子や徘䧃などを防止し，介護・ 福祉分野へ貢献できる。ここで, 位置情報を伝えるセ ンサの電源として電磁誘導型振動発電装置が用いられ ている[5]。電磁誘導方式の特徴は電気的な内部抵抗が 低く [3], 磁気回路設計の自由度が高い点である。発電

連絡先：北山 文矢, $\overline{\mathbf{T}} 316-8511$ 茨城県日立市中成沢町 412-1, 茨城大学工学部機械システム工学科

e-mail: fumiya.kitayama.amayatik@vc.ibaraki.ac.jp

*1 茨城大学
装置は見守り対象者の脚部に取り付けられ，振動エネ ルギーを電気エネルギーに変換している。

このような電源供給を用いた見守りシステムの利 便性向上のためには，頻繁な通信をすることや長時間 駆動すること，心拍数などの位置情報以外のデータを 送ることなどが必要とされる。これらの要求を満たす ためには更なる発電量の向上が求められる。電磁誘導 を用いた歩行発電では最適な負荷抵抗の選定[6]やコ イルターン数の増加が発電量の向上のために有効であ るが，磁石配置の影響は未だ明らかにされていない。 そこで, 本研究ではハルバッハ配置[7]を基にした磁束 集中配置を発電装置へ適用し，発電量への寄与を明ら かにする。まず, 電磁誘導型振動発電装置の基本構造, 発電原理, 磁石配置を示す。本稿では比較のために, 従来の見守り用振動発電装置で採用されている N-S 配 置もしくは磁束集中配置を適用する。次に, 各磁石配 置を適用した発電装置における逆起電圧定数と磁束密 度分布を磁場解析より求める。また，各磁石配置の簡 易モデルを製作し, 磁石表面の磁束密度を測定し, 解 析結果と比較する。逆起電圧定数および歩行時の脚部 加速度を用いて発電量を数值計算により求め, 磁束集 中配置の効果を明らかにする。

\section{2 電磁誘導型振動発電}

\section{1 発電装置の基本構造}

Fig. 1 に本研究で対象とする発電装置の基本構造を 
示す。本装置は可動子と固定子で構成される。可動子 は残留磁束密度 $1.3 \mathrm{~T}$ のネオジム磁石とヨーク, そし てヨークを保持するための塩化ビニル製部品からなり， 可動子質量は約 $15 \mathrm{~g}$ である。ここで, 保持部品は摺動 部としても使用する。小型化の観点からヨークの厚さ は $1 \mathrm{~mm}$ に制限する。一方, 固定子は線径 $0.3 \mathrm{~mm}$, 夕 ーン数 85 Turns のコイルとボビン, ケースから構成さ れる。可動子はバネで繋がれており, ケース内部で支 持され，ボビンに沿って振動する。デバイスの小型な 外形を維持しつつ, 可動子の共振周波数を脚部の振動 の周波数にできるだけ近づけるためにバネは $3 \mathrm{~N} / \mathrm{m} の$ ものを使用寸る。また，ケースにはスリットが設けら れており, 保持部品はこのスリットと摺動接触できる ように突起を持たせてある。スリットの長さは $10 \mathrm{~mm}$ とした。

次に発電原理について示す。まず, 歩行動作によっ て本装置の固定子が励振され, それに伴い可動子がバ ネの復元力によって振動する。そして，コイルの鎖交 磁束数の変化により, 逆起電力が発生し, コイルに接 続された外部回路に電力が蓄えられる。このとき誘導 電流によって可動子に電磁力が生じる。したがって, 本発電装置の運動系は Fig. 2 に示寸ようなバネ-マスダンパ系とみなせ，下式の運動方程式で表される。

$m \ddot{x}_{2}(t)+c \dot{x}_{2}(t)+k x_{2}(t)=c \dot{x}_{1}(t)+k x_{1}(t)+F(t)(1)$ ここで, $x_{1}(t)$ と $x_{2}(t)$ はそれぞれ固定子の変位, 可動子 の変位であり, $m$ は可動子の質量, $c$ は粘性減衰係数, $k$ はバネ定数である。また, 電磁力 $F(t)$ は逆起電圧定数 $\alpha$ と誘導電流 $I(t)$ を用いて $F(t)=\alpha I(t)$ と表すことが できる。さらに, 相対変位 $x_{r}(t)=\left(x_{2}(t)-x_{1}(t)\right)$ を用 いることで式(1)は次のように書き換えられる。

$$
m \ddot{x}_{r}(t)+c \dot{x}_{r}(t)+k x_{r}(t)=-m \ddot{x}_{1}(t)+\alpha I(t)
$$

また，本装置の電気回路はコイルとセンサなどの負荷 から構成され, 式(3)の電気回路方程式で表される。

$$
\frac{\partial \phi\left(x_{r}, I\right)}{\partial x_{r}(t)} \frac{d x_{r}(t)}{d t}+\frac{\partial \phi\left(x_{r}, I\right)}{\partial I(t)} \frac{d I(t)}{d t}+R I(t)=0
$$

ここで $\phi\left(x_{r}, I\right)$ はコイルの鎖交磁束数, Iは誘導電流, $R$ はコイル抵抗 $R_{1}$ と負荷抵抗 $R_{2}$ を用いて $R=R_{1}+R_{2}$ で表される電気回路全体における抵抗值である。

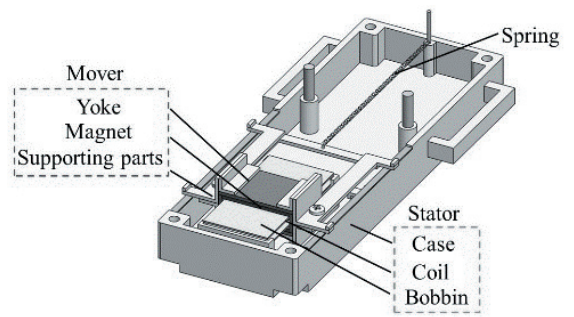

Fig. 1 Structure of vibration generator.

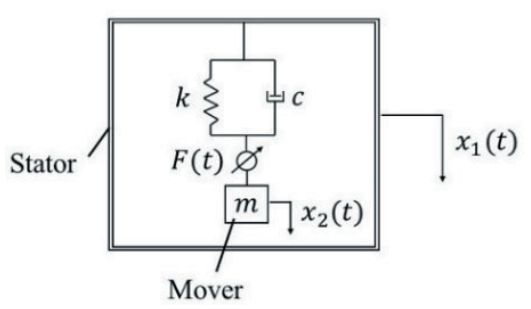

Fig. 2 Dynamic model of vibration generator.

\section{2 磁石配置}

\subsubsection{N-S 配置}

本稿では 2 種類の磁石配置を用いる。1 つは従来の 見守り用振動発電装置にも使われている磁石配置であ り，N-S 配置と呼ぶことと寸る。 N-S 配置は上下に磁 化された磁石を使用し，磁極を逆向きにして並べる。 磁石は幅 $7.5 \mathrm{~mm}$, 長さ $21 \mathrm{~mm}$, 厚さ $1 \mathrm{~mm}$ のものを 4 枚使用寸る。このように使用する磁石が同形状かつ少 数であることが特徽である。Fig. 3 に可動子の磁気回 路とコイルを抽出した発電装置の全体図を示し，断面 $S$ を定義する。Fig. 4 に断面Sにおける N-S 配置を用い た発電装置と磁束の流れを示す。図中の $x$ 軸が可動子 の振動する方向である。Fig. 4 の状態ではz軸の正と負 の方向にコイルに対して同数の磁束が直交するため, 鎖交磁束が $0 \mathrm{~Wb}$ となる。しかし, 磁石がx軸方向に動 くと, 磁束がコイルに対して鎖交状に流れ, 鎖交磁束 数が正もしくは負の值となる。これにより十分な発電 量の確保が可能である。

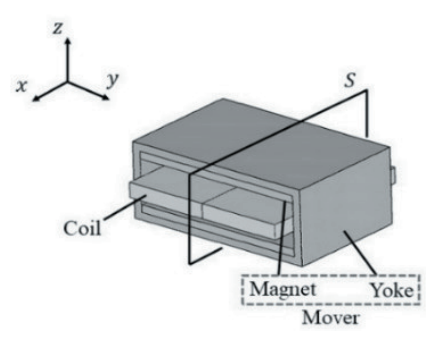

Fig. 3 Detail view of device without non-ferromagnetic materials. 


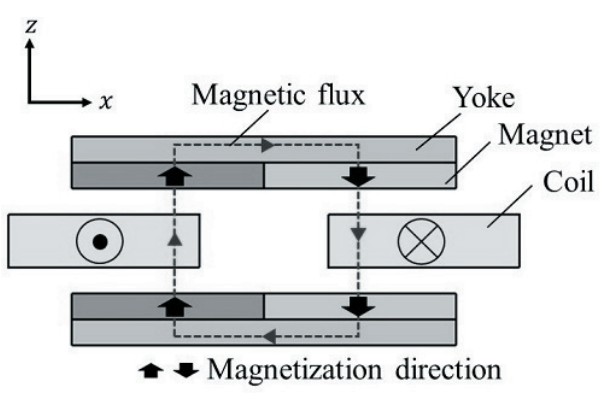

Fig. 4 N-S array.

\subsection{2 磁束集中配置}

2 つ目の磁石配置はハルバッハ配置を基に磁石を配 置した磁束集中配置である。Fig. 5 に断面 $S$ における磁 束集中配置と磁束の流れを示す。磁束集中配置では, N-S 配置の磁石の間に, N-S 配置に対して垂直な磁化 方向を持つ磁石が追加されている。それぞれの磁石は 長さが $21 \mathrm{~mm}$, 厚さが $1 \mathrm{~mm}$ である。幅は左右の磁石 が $6 \mathrm{~mm}$, 中央の磁石は $3 \mathrm{~mm}$ である。Fig. 5 に示すよ うに，エアギャップ領域で磁束の強めあいが起こる。 これにより, 局所的に鎖交磁束数が増加する。さらに, 上下のヨーク部分では磁束の弱めあいが起こり，磁気 飽和を防ぐことができる。このように，磁束集中配置 を適用することで鎖交磁束数およびその変化量が増加 し，発電量も向上できると考える。

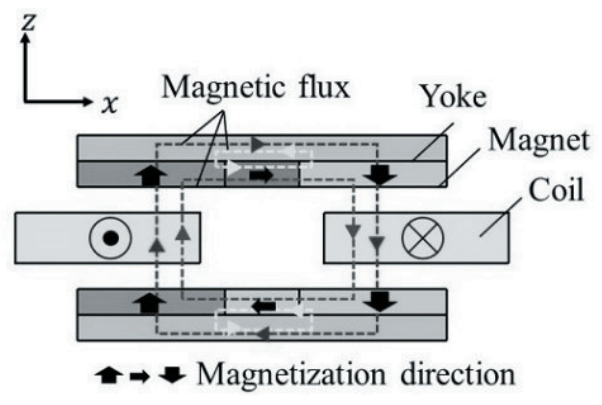

Fig. 5 Concentrated flux array.

\section{3 逆起電圧定数および磁束密度の評価}

\section{1 磁場解析による逆起電圧定数の算出}

鎖交磁束 $\phi$ 位置と電流の関数 $\phi(x, I)$ であると仮定 すると, 電磁誘導によって生じる誘導起電圧は式(3)の 左辺第一項と第二項で表される。本稿で対象とする発 電装置では第一項により発電される。ここで,

$$
\alpha=\frac{\partial \phi(x, I)}{\partial x}
$$

とおき, 逆起電圧定数 $\alpha$ を定義する。このように可動子 速度による逆起電圧は逆起電圧定数 $\alpha$ と相対速度 $d x_{r}(t) / d t$ に比例して大きくなる。三次元有限要素法を 用いた磁場解析ソフトウェア femeem[8]を使用して, 可動子と固定子の相対変位をー $10 \mathrm{~mm}$ から $10 \mathrm{~mm}$ まで $1 \mathrm{~mm}$ 毎に固定した際の鎖交磁束数を求めた。そして 鎖交磁束数の差と相対変位の差から逆起電圧定数を式 (4)により算出した。Fig. 6 に鎖交磁束数, Fig. 7 に逆 起電圧定数を示す。Fig. 6, Fig. 7 より磁束集中配置に することで鎖交磁束数が増加し，逆起電圧定数が大き くなったことがわかる。Fig. 8 に相対変位 $0 \mathrm{~mm}$ におけ る磁束密度のコンター図と発電装置中心の断面のベク トル図を示す。Fig. 8(a)の N-S 配置ではヨークの上下 面で磁気飽和が起こっており，磁束密度の最大值は約 $2.1 \mathrm{~T}$ であった。Fig. 8(b)の磁束集中配置ではヨーク内 の最大磁束密度は約 $1.8 \mathrm{~T}$ であり，磁気飽和を起こし ていなかった。また，Fig.8(c)と Fig. 8(d)より，磁束集 中配置では前述した磁束の弱めあいが起こっている。 これにより磁気飽和を回避していると考えられる。ま た，Fig. 8(c)と Fig. 8(d)におけるヨーク内の最大磁束密 度はそれぞれ約 $2.1 \mathrm{~T}$ ，約 $1.7 \mathrm{~T}$ であった。

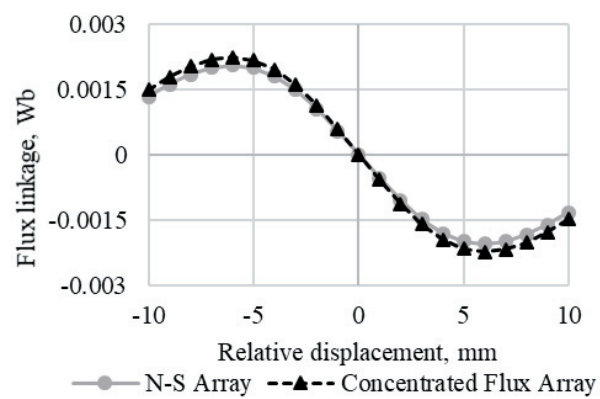

Fig. 6 Analytic value of flux linkage.

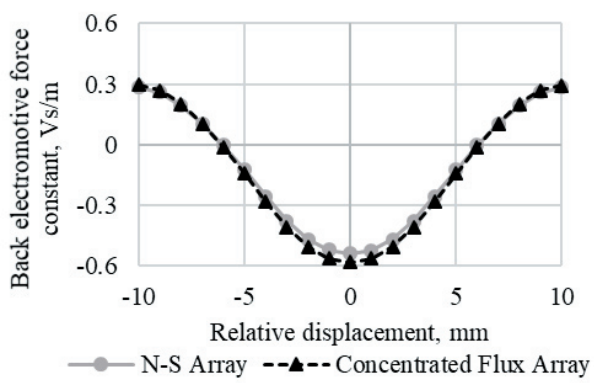

Fig. 7 Back electromotive force constant. 

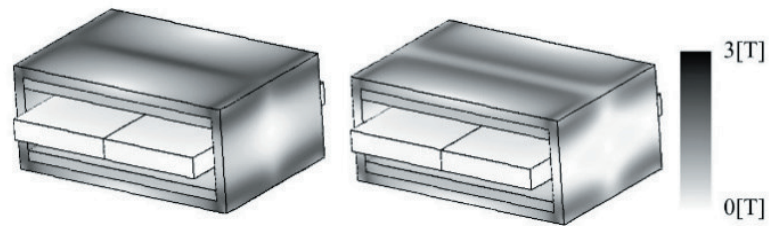

(a) N-S array (3D).

(b) Concentrated flux array(3D).

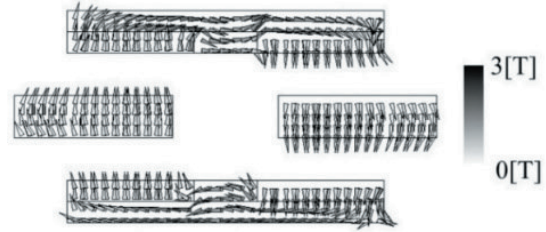

(c) N-S array (A cross sectional view).

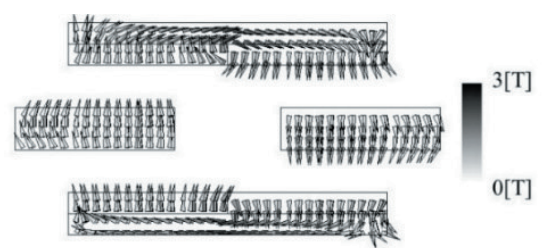

(d) Concentrated flux array (A cross sectional view).

Fig. 8 Magnetic flux density.

3.2 簡易モデルを用いた磁束密度の測定

次に可動子の一部を模擬した簡易モデルの試作機 を用いて, 磁束集中配置の効果を検証する。Fig. 3 にお ける Mover をフルモデルとすると, 簡易モデルはフル モデルの下側を模擬しており, 幅 $3 \mathrm{~mm}$, 長さ $14 \mathrm{~mm}$, 厚さ $1 \mathrm{~mm}$ の磁石とヨークで構成する。まず, 簡易モ デルがフルモデルと同様の特性であることを静磁場解 析により確認する。Fig. 9 に簡易モデルの短手方向の 中心において切り出した断面図における, 磁束密度分 布を示す。Fig. 9(a) と Fig.9(b)は z 方向の磁束密度分布, Fig. 9(c)と Fig. 9(d)は三軸方向の磁束密度の分布である。 上から一層目が磁石，二層目がヨークである。磁石側 の空気層を見ると, Fig. 9(a)に比べ, Fig. 9(b)では一層 目の両側にある磁石の近傍で磁束密度が大きくなって いる。また, Fig. 9(c)と Fig. 9(d)より, 磁束集中配置で は磁束の打ち消しあいが確認できる。これにより磁気 飽和を防止できると考えられる。また, Fig. 9(c)と Fig. 9(d)におけるヨーク内の最大磁束密度はそれぞれ約 $2.4 \mathrm{~T}$, 約 $2.0 \mathrm{~T}$ であった。以上より, 簡易モデルでも 磁束集中配置における磁気飽和の防止効果および磁石 表面における磁束の増加がみられるため, フルモデル と同様の傾向があると判断した。次に, $1 \mathrm{~mm} \times 1 \mathrm{~mm} \times$ $1 \mathrm{~mm}$ の磁石を 6 個, $3 \mathrm{~mm} \times 3 \mathrm{~mm} \times 1 \mathrm{~mm}$ の磁石を 4
個組み合わせて簡易モデルを製作し， z 方向における 磁石表面の磁束密度を測定した。また，比較のために 測定位置の $\mathrm{z}$ 方向の磁束密度を磁場解析でも求める。 測定に用いた磁石の残留磁束密度はカタログ值で 1.17 〜 $1.22 \mathrm{~T}$ である。実験装置を Fig. 10 に示す。レーザ変 位センサ（オプテックス・エフエー，CD22-35V）を用 いてガウスメーター（Lake Shore Cryotronics Inc., Model 421 Gaussmeter) のプローブを簡易モデルの磁石表面と 平行に設置した。この時, 磁石表面とプローブの測定 面の間隔は約 $1.15 \mathrm{~mm}$ であった。次に，XY 軸ステー ジ (中央精機, LD-149-C1) によってプローブの測定点 を試作機の短手方向へ移動させ，最大磁束密度を計測 した位置で固定した。その後, 長手方向へ移動させる ことで $\mathrm{z}$ 方向の磁束密度分布を測定した。次に，短手 方向の近傍 $00.1 \mathrm{~mm}$ で固定し同様に測定した。そして, 合計 3 回の算術平均を求めた。解析ではプローブの厚 さ $1 \mathrm{~mm}$ 考慮し, 磁石表面から $\mathrm{z}$ 方向 $1.15 \mathrm{~mm} 1.65$ $\mathrm{mm}$ 間の磁束密度の平均值を測定位置毎に求めた。測 定值と解析值の比較を Fig. 11 に示す。Fig. 11 を見る と, 解析では測定位置 $x$ が $x \leq-2 \mathrm{~mm}$ と $2 \mathrm{~mm} \leq x の$ 範囲で磁束集中配置の磁束密度が大きくなっている。 しかし，測定では $x \leq-2 \mathrm{~mm}$ と $2 \mathrm{~mm} \leq x$ の範囲で解 析と同様の傾向は見られず，解析值と測定值が同じ傾 向を示しているとは言えない。さらに，x=-3 mmの 時の N-S 配置の実験值を見ると, 近傍の值に比べて磁 束密度が著しく小さかった。本実験方法では，プロー ブは各軸方向に拘束されているため, プローブのずれ によって解析值と測定值の誤差が生じたとは考えにく い。一方で，簡易モデルの製作方法に着目すると，磁 石を多数貼りつけるためにすき間が多くなる。それに より, 特定位置での磁束密度の低下が生じたと考えら れる。このように, 試作機が解析モデルと同様の磁気 回路でないため, 測定值が解析值と異なる傾向を示し た。そのため，製作方法を改善して再検証をする必要 がある。

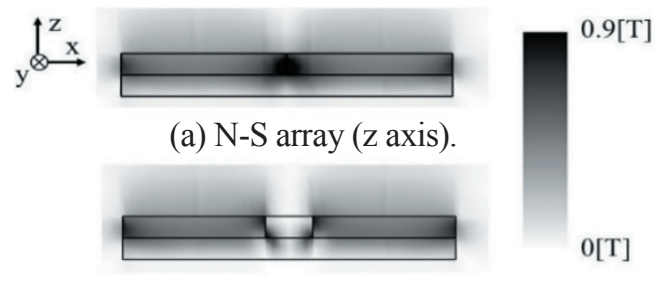

(b) Concentrated flux array ( $\mathrm{z}$ axis).

Fig. 9 Magnetic flux density in simple model. 


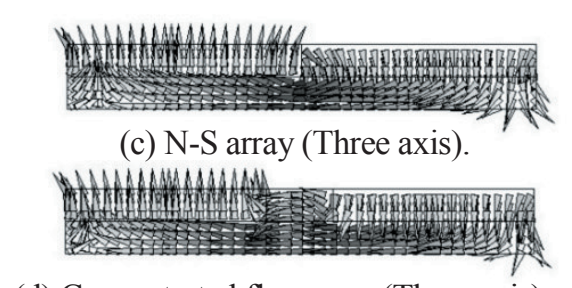

(d) Concentrated flux array (Three axis).

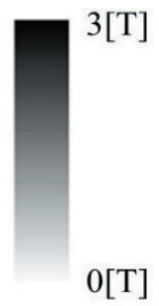

Fig. 9 Magnetic flux density in simple model (continued).

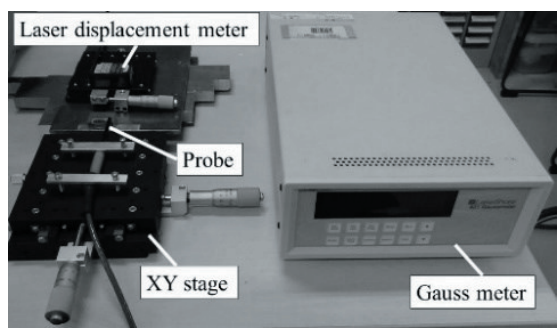

Fig. 10 Magnetic flux density measurement.

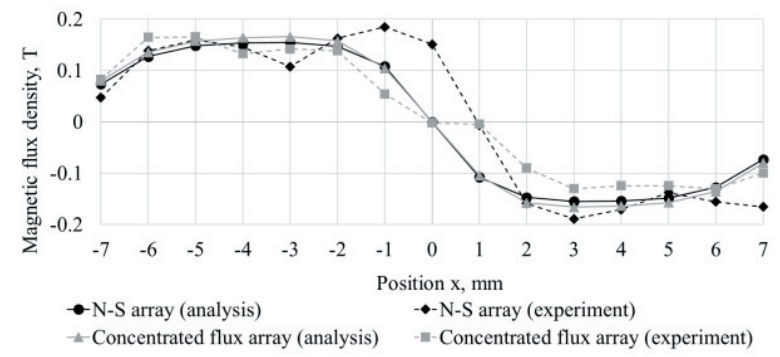

Fig. 11 Comparison of analyzed and experimental values.

\section{4 発電量の評価}

\section{1 脚部加速度の測定}

歩行発電における発電量を算出するために，発電源 となる歩行時の脚部振動を測定する。脚部加速度の測 定には 3 軸加速度センサ（Arduino LLC，Genuino101） を用いた。被験者は 20 代男性 2 名である。Fig. 12 に 示すように大腿部の横側に加速度センサを取り付け, 平坦路を約 1 分間歩行し, 加速度を測定した。加速度 センサはPC とケーブルを介して接続され, $10 \mathrm{~ms}$ 毎に データが送信される。また，ケーブルが歩行の邪魔に ならないように被験者の他に実験者が PC を持ち, 自 然な歩行ができるように配慮した。Fig. 13 に測定開始 から 10 秒までの被験者 1 の鉛直方向における脚部加 速度を示す。本測定および文献[9]では，3 軸方向の中 で，鉛直方向の加速度振幅が一番大きいため，鉛直方 向の振動に着目した。Fig. 13 に示すように，脚部の振 動は重畳振動であることがわかる。また，センサが鉛 直方向に-1 G の重力加速度を検知している。厳密な

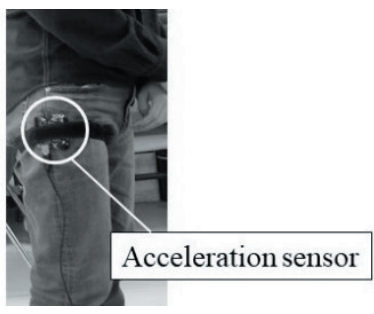

Fig. 12 Measurement of leg acceleration.

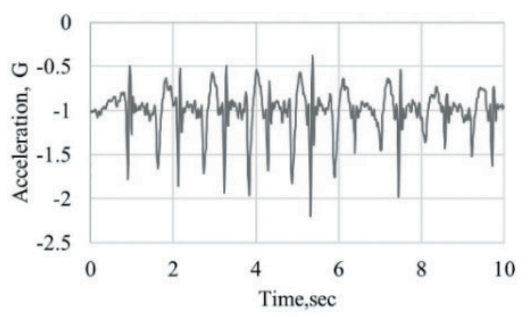

Fig. 13 Acceleration in waking.

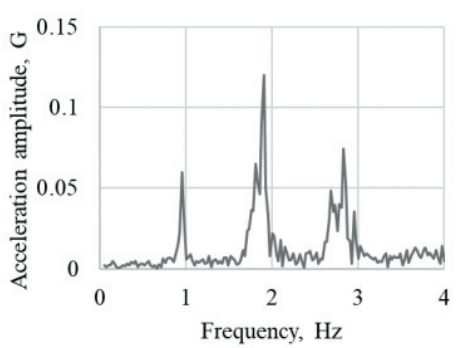

Fig. 14 FFT analyzed result in walking vibration.

評価のためにはこの成分を除去する必要があるが，本 稿では簡易的な検討とし, 補正として測定值に $1 \mathrm{G}$ を 加算して補正した加速度を発電シミュレーションにお ける入力波形とする。さらに，脚部に発生する振動の 周波数を推定するため, FFT(Fast Fourier Transformation) 解析を行い，その結果を Fig. 14 に示す。Fig. 14 に示す 通り，脚部における振動にはいくつかの周波数成分が 見られるが，脚部振動の加速度振幅が最大となる周波 数は約 $1.9 \mathrm{~Hz}$ であった。これは文献[9]の結果とおおむ ね一致しているため, 測定精度は十分であると考えた。

\section{2 数值計算による発電量の比較}

N-S 配置と磁束集中配置において, 歩行時の脚部加 速度を入力とした発電シミュレーションを行う。式(2) と式(3)から誘導電流 $I(t)$ を求女, 以下の $(5)$ 式から負荷 における消費電力 $P(t)$ を計算し, シミュレーション時 間 $30 \mathrm{~s}$ で除した平均電力で比較する。また，シミュレ ーションの計算周期は $1 \times 10^{-4} \mathrm{~s}$ とした。 


$$
P(t)=I(t)^{2} R_{2}
$$

シミュレーションでは可動子質量を $15 \mathrm{~g}$ とし, 磁石配 置を変えることによる摩擦力の変化は無いため粘性減 衰係数を一定值 $(1 \mathrm{Ns} / \mathrm{m})$ とした。また, バネ定数を 3 $\mathrm{N} / \mathrm{m}$, コイルターン数を 85 Turns, インダクタンスは静 磁場解析から算出した定数 $2.37 \times 10^{-4} \mathrm{H}$ とした。そ して, コイル抵抗と負荷抵抗をともに $1.03 \Omega$ とした。 ここで，可動子共振周波数は $2.25 \mathrm{~Hz}$ となる。Fig. 7 の 結果は線形補間され，相対変位 $x_{r}$ に応じて值を出力寸 るようにした。このときの N-S 配置と磁束集中配置に おける電力の差と誘導電流の差をFig. 15 に示寸。また, シミュレーション開始時から 2.5 秒までの相対変位一 相対速度のグラフを Fig. 16 に示す。Fig. 15 より, 磁束 集中配置にすることで最大で $0.2 \mathrm{~mW}$ 電力が上昇した。 また, 平均電力は $\mathrm{N}-\mathrm{S}$ 配置が $0.0463 \mathrm{~mW}$, 磁束集中配 置が $0.0529 \mathrm{~mW}$ となり, 提案した磁石配置にすること で約 14\%発電量が向上した。また, 誘導電流は磁束集 中配置にすることで最大 $2.5 \mathrm{~mA}$ 上昇したが, 最大值 は $40 \mathrm{~mA}$ 以内であり, 発熱の心配はない。そして, Fig. 16 から振幅は約 $6 \mathrm{~mm}$ であり, ケースのスリッドの範 囲内である。また，相対速度が $30 \mathrm{~mm} / \mathrm{s}$ 以上のとき， 相対変位は $-5 \mathrm{~mm} \leq x_{r} \leq 5 \mathrm{~mm}$ となる。この範囲で は相対速度が大きいため, 逆起電圧が得られるといえ る。相対変位がこの範囲内にあるとき, 逆起電圧定数 はFig. 7 に示すように磁束集中配置の方が大きくなる。 したがって, 磁束集中配置を用いることで相対変位が $-5 \mathrm{~mm} \leq x_{r} \leq 5 \mathrm{~mm}$ での逆起電圧定数が増加し, 発 電量が向上したと考えられる。

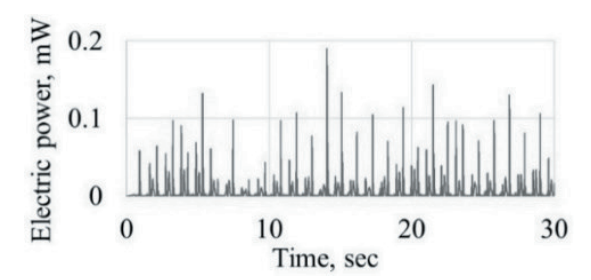

(a) Electric power.

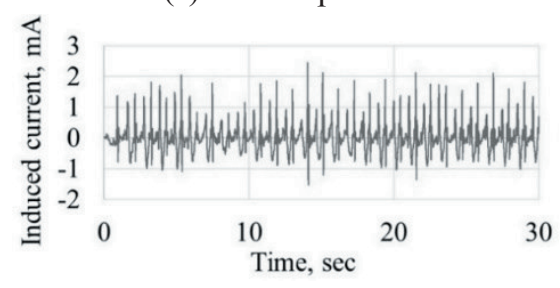

(b) Induced current.

Fig. 15 Difference in N-S and concentrated flux array.

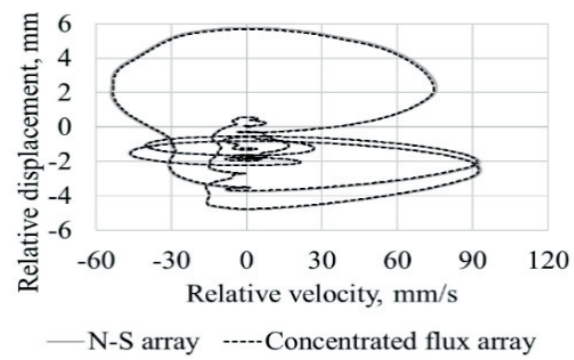

Fig. 16 Relative displacement against velocity.

\section{5 結言}

本稿では，ハルバッ八配置を基にした磁束集中配置 を電磁誘導型振動発電装置に適用した。磁場解析から 逆起電圧定数を算出した結果, 従来の磁石配置と比心゙ て, 磁束集中配置を用いた発電装置では相対変位が-5 $\mathrm{mm}$ から $5 \mathrm{~mm}$ の範囲で大きな逆起電圧定数が得られ た。脚部加速度を用いた発電シミュレーションの結果 から, 磁束集中配置が発電量に寄与寸ることを示した。 今後は，試作機の製作方法，および製作性を考慮した 最適化形状の検討および磁束集中配置を適用した発電 装置の製作をする。そして, 脚部に取り付けた状態で 歩行し, 発電量を測定した後, 解析值と比較寸る。

\section{参考文献}

[1] 神野伊策, 振動発電による MEMS エナジーハーベスト技 術，システム/制御情報，Vol.58, No. 11, pp. 443-448, 2014.

[2] 鈴木雄二, 環境発電技術の展望, 日本 AEM 学会誌, Vol.22, No.3, pp. 339-342, 2014.

[3] 井上竜太, 振動発電を利用したエコ工事振動対策技術の 開発，竹中技術研究報告，No. 68, pp. 1-8, 2012.

[4] 神野伊策, 振動エネルギーによる環境発電 (振動発電), 表面技術，Vol.67, No.7, pp. 348-352, 2016.

[5] 保坂寬, ウェアラブル情報機器のための振動発電技術, 電気学会誌， 126 巻， 4 号， 2006.

[6] N.G. Stephen, On energy harvesting from ambient vibration, Journal of Sound and Vibration 293, pp. 409-425, 2006.

[7] 木村貴裕, 高山佳久, 近藤孝広, 雉本信哉, 組み合わせ 磁石を用いた磁気ダンパの研究（基本ハルバッ八配列磁 石を用いた磁気ダンパ), 日本機械学会論文集 (C 編), 78 巻, 789 号, pp. 1693-1694, 2012.

[8] 河瀨順洋, 山口忠, 北川亘, 回転機の電磁場解析実用化 技術と設計法，科学情報出版株式会社，2016.

[9] 大上裕也, 橋山智訓, 岩田満, 田野俊一, 3 軸加速度セン サを用いた歩行パターンの分類, ファジィシステムシン ポジウム講演論文集, Vol.22, pp. 506-511, 2006. 